\title{
Lukács and the Limitations of Zolaesque Naturalism: A Critical Approach to Dreiser's Sister Carrie
}

\author{
Hossein Fathi Pishosta \\ Member of the Academic Board of Rafsanjan Vali-e-Asr University, Rafsanjan, Kerman (IRAN) \\ Corresponding author's email: fathi.hoss@gmail.com
}

\section{Doi:10.5901/mjss.2016.v7n2s1p225}

\section{Abstract}

This study addresses Georg Lukács' critique of Zolaesque naturalism; for this purpose it draws on Theodore Dreiser's novel Sister Carrie as a case study. As a champion of realist novel, Lukacs emphasizes the totality of human experience and those dimensions of reality that are permanent and are objectively depicted in the works of art. From this perspective, he presents his critique of Zola's scientific method which, according to him, distorts reality, always seeks the average and is blind to the completeness of human experience. In this study, it is argued that a reading of Dreiser's Sister Carrie in the light of Zola's ideology testifies to the fact that although the philosophical roots of naturalism in America have been associated mainly with Zola's ideology but in some cases like Dreiser's Sister Carrie Zola's tenets prove to be inadequate or inept. This is in line with

Keywords: Lukacs, Zolaesque naturalism, Dreiser, Sister Carrie

\section{Introduction}

The Hungarian Marxist philosopher and critic Georg Lukács (1885 -1971) in "The Ideology of Modernism" presents his defense of the realist tradition of literature along with his sharp critique of modernism for its neglect of an objective reality. As he highlights, the human subject depicted by the modernist writers is "by nature solitary, asocial, unable to enter into relationships with other human beings" (1964, p.20). For Lukács, characteristic of modern literary schools, from naturalism to surrealism, is that they all "take reality exactly as it manifests itself to the writer and the characters he creates. The form of this immediate manifestation changes as society changes" (2007, p. 33); hence the modernist writers fail to capture the fundamental relations of the socio-historical conditions that constitute the true and real nature of the modern subject. They "remain frozen in their own immediacy; they fail to pierce the surface to discover the underlying essence, i.e., the real factors that relate their experiences to the hidden social forces that produce them" (ibid., p.33). Lukács' defense of realist novel which he regards as the culmination of the narrative form finds also its vivid expression in his book Studies in European Realism (1964). As he states:

The true great realism depicts man and society as complete entities, instead of showing merely one or the other of their aspects.... realism means a three-dimensionality, an all roundness, that endows with independent life characters and human relationships. (p. 6)

The central category and criterion of great realist literature, for Lukacs, is the concept of the 'type':

a peculiar synthesis which organically binds together the general and the particular both in characters and situations. What makes a type a type is not its average quality, nor its mere individual being, however profoundly conceived; what makes it a type is that in it all the humanly and socially determinants are present on their highest level of development, in the ultimate unfolding of the possibilities latent in them, in extreme presentation of their extremes, rendering concrete the picks and limits of men and epochs. (ibid.)

Types, as Lukács argues, are "figures of exceptional qualities, who mirror all essential aspects of some definite stage of development, evolutionary tendency or social group" (p.71). For him, the great realist novelists, like Balzac or Tolstoy, manage to depict the totality of human experience in its social context. Advocating proletarian humanism, he mentions that the object of proletarian humanism is "to reconstruct the complete human personality and free it from the distortion and dismemberment to which it has been subjected in class society" (p. 5). Great arts, indeed, depict man as a whole in the whole of society. Hence, true or critical realism requires that the writer not only depict segments or dimensions of reality that are immediately obvious, but also those aspects that are permanent and objectively more 
significant.

Given this view of art, he puts forward his attack on the 'naturalism' of Emile Zola and critiques its destruction of the completeness of the human personality. Drawing on the conflict between naturalism and realism, he observes that realism is based on the "the recognition of the fact that a work of literature can rest neither on a lifeless average, as the naturalists suppose, nor on an individual principle which dissolves its own self into nothingness" (p. 6). He claims that the trivial photographic naturalism of Zola distorts reality and presents it just as a lifeless average. For him, the hall-mark of the work of great realist novelists like Balzac is a "ruthlessness towards their own subjective world-picture" (p.31); from this perspective, he challenges the pseudo-objectivism of the naturalist school. Lukacs' critique of Zolaesque naturalism reaches its climax when he states that:

Zola's method, which hampered not only Zola himself but his whole generation, because it was a result of the writer's position as solitary observer, prevents any profoundly realistic representation of life. Zola's 'scientific' method always seeks the average, and this grey statistical mean, the point at which all internal contradictions are blunted, where the great and the petty, the noble and the base, the beautiful and the ugly are all mediocre 'products' together, spells the doom of great literature. (ibid. p.91)

Lukács' pronouncements on Zolaesque naturalism and its limitations find their vivid expression in addressing Theodor Dreiser's novel Sister Carrie (1900) from a naturalist perspective.

\title{
2. Discussion
}

Emile Zola in Naturalism on the Stage (as cited in Selden, 2014) views naturalism as a "return to nature and to man, direct observation, exact anatomy .... No more abstract characters in books, no more lying inventions, no more of the absolute; but real characters, the true history of each one, the story of daily life" (p. 54). From the first, "the philosophical roots of naturalism in America have been firmly associated with the pronouncements and fiction of Emile Zola, and especially with Zola's 1880 defense of literary naturalism in The Experimental Novel" (Pizer, 1999, p.1). In this work Zola (1963) advances the idea that the task of a novelist is not just reporting facts as one observes them; the novelist is like an experimentalist who conducts an experiment in his fictional laboratory: he "sets the characters of a particular study in motion, in order to show that the series of events therein will be those demanded by the determinism of the phenomenon under study" (p.166). Dreiser's novel Sister Carrie has generally been judged to be inadequate or inept in terms of its adherence to the tenets of naturalism.

The novel depicts the story of a naive eighteen-year-old girl called Carrie Meeber who leaves her rural Wisconsin home in quest of a better life to Chicago, where her older sister Minnie lives. As Dreiser (1981) states:

\begin{abstract}
When a girl leaves her home at eighteen, she does one of two things. Either she falls into saving hands and becomes better, or she rapidly assumes the cosmopolitan standard of virtue and becomes worse. Of an intermediate balance, under the circumstances, there is no possibility. The city has its cunning wiles no less than the infinitely smaller and more human tempter. There are large forces which allure, with all the soulfulness of expression possible in the most cultured human. The gleam of a thousand lights is often as effective, to all moral intents and purposes, as the persuasive light in a wooing and fascinating eye. Half the undoing of the unsophisticated and natural mind is accomplished by forces wholly superhuman. (pp. 3-4, my italic)
\end{abstract}

Carrie's quest exposes her to conditions and forces which have the power of undoing her unsophisticated and natural mind; being a waif amid forces, she is nonetheless determined to pave her way in the big city for success. Carrie's hopes are somewhat dashed when she finally obtains a job in a shoe factory at four and a half dollars a week. This is finally followed by her rise to a successful stage actress; she achieves what she had hoped for before: money, finery and prestige. Carrie's rise to happiness and glory is depicted in contrast to that of George Hurstwood, a member of the upper middle class who falls from his 'walled city' of comfortable lifestyle when his business savings dwindle; as a result he loses his dignity and pride and finally resigns himself too readily to a life on the streets until he commits suicide.

The novel has given rise to divergent perspectives in terms of its adherence to the tenets of naturalism. On the one hand, as Hakutani (1967) observes, some critics have highlighted Dreiser's adherence to the deterministic view of human condition:

One of the major reasons why this novel was frowned upon in 1900 was precisely Dreiser's obvious adherence to the deterministic view of human conditions. Many of his early critics considered Dreiser to be solely a victim of the so-called central truth about man as he saw it. They felt that he knew no more or no less than this crudely generalized 
mechanism of man - the theory that man is an animal subject to no human law but only the law of his own instinct, behaving as he desired, controlled only by natural forces. (p. 3)

On the other hand, a second group of critics have argued that "Dreiser made no contribution to the theory and technique of the novel in American literature" in this regard (ibid.). These critics have pointed out the limitations of Zolaesque naturalism when applied to Dreiser's novel.

According to Pizer (1999), the first problem with looking for "a clear expression of Zolaesque deterministic ideas in fiction presumed to be naturalistic" is that the critic might fail to find these ideas in the fiction (p. 2). Throughout the novel, the issue of determinism versus free will appears as a central concern. Dissatisfied with her life in rural Wisconsin home, Caroline Meeber (Sister Carrie) moves to Chicago where she starts realizing her own ambitions. In Contrast to the rapidly aging Hurstwood who declines into obscurity, Carrie begins to fulfill her quest of beauty and happiness and becomes a famous actress and, as Wald (2004) states, she does not become "the fallen woman of the common melodramas: scarred, discarded, and consigned to the margins" (p. 188). Dreiser thus significantly "rewrites the familiar binary which aligns women with emotion and weakness, and men with intellect and strength" (Eby, 2004, p. 146). From this perspective, Carrie's rise to success and stardom is in conflict with the metaphor of a wisp in the wind presented by the writer in chapter eight of the novel:

\begin{abstract}
Among the forces which sweep and play throughout the universe, untutored man is but a wisp in the wind ... We see man far removed from the lairs of the jungles, his innate instincts dulled by too near an approach to free-will, his freewill not sufficiently developed to replace his instincts and afford him perfect guidance... He is even as a wisp in the wind, moved by every breath of passion, acting now by his will and now by his instincts, erring with one, only to retrieve by the other, falling by one, only to rise by the other--a creature of incalculable variability. In Carrie--as in how many of our worldlings do they not?-- instinct and reason, desire and understanding, were at war for the mastery. She followed whither her craving led. She was as yet more drawn than she drew. (p. 73)
\end{abstract}

The novel in this way proves the failure of the connection between naturalist ideology and Dreiser's depiction of it. Nevertheless, as Pizer mentions, the novel contains many of the characteristics traditionally associated with literary naturalism in the portrayal of Hurstwood, since it presents "a brief glance at a bio chemical explanation of behavior and a close account of the decline of a character in the context of an urban setting" (ibid., p.4).

Another problem with a naturalist reading of Dreiser's Sister Carrie is that the novelist presents very little background information regarding Carrie or Hurstwood:

\begin{abstract}
Dreiser in the novel either thinly or confusingly depicts the sources of character within a genetic or environmental determinism. Very little of Carrie's background is available, for example, as a basis for understanding the origin of her nature or actions, since we are told almost nothing about her parents or of her life before she comes to Chicago as a young woman. She is thus more a blank to be written upon by her adult experience than a figure fully shaped by her origins. As for Hurstwood, we again know nothing of his early life. (ibid. )
\end{abstract}

Another aspect of Carrier's flawed naturalism is that "the city as environment plays a seemingly contradictory role in the lives of the two principal characters" (ibid), a point suggested in the reversal fortune of Carrie and Hurtswood. Carrie's success in her quest of beauty and happiness has led Seltzer (1976) to conclude that despite Dreiser's sometimes deterministic explanations of Carrie's behavior, "his heroine emerges more as a creature of romance than as a fictional by-product of naturalistic dogma" (p.193).

Giles (2004) in his remarks on Dreiser's style notes that it mediates between two different conceptions of truth: "the received wisdom of social custom on the one hand and the uncertainties of philosophical agnosticism on the other" (p.54), and that "in both its formal style and its thematic content Sister Carrie ostensibly abjures the notion of an active design and sets itself to reflect instead a heterogonous world that already exists" (ibid.).

\title{
3. Conclusion
}

From the beginning the ideological roots of Naturalism in America have been mainly associated with Emile Zola's pronouncements and fiction; however, Zolaesque naturalism has its own shortcomings when applied rigidly to a novel like Dreiser's Sister Carrie that is regarded by some, not all, critics as a naturalist novel. Critics have referred to the conflicts in the novel regarding Dreiser's presentation of a deterministic view of life, a point that is proved in Dreiser's depiction of the reversal fortune of the novel's two central characters Carrie Meeber and George Hurstwood. Elements such as the little background information in the novel about the lives of the two principle characters and the contradictory role of the 
city in forming their fortune are among other shortcomings suggested by critics regarding a naturalist reading of the novel.

These observations regarding the heterogeneous world of Sister Carrie and the conflict resulting from Zolaesque ideology and Dreiser's depiction of the issue in the novel are in line with Lukacs' critique of Zola's scientific method which according to him distorts reality and seeks the average, the point at which all internal contradictions are blunted.

\section{References}

Dreiser, T. (1981). Sister Carrie. Philadelphia: University of Pennsylvania Press.

Eby, C. V. (2004). Dreiser and Women. In L. Cassuto \& C. V. Eby (Eds.), The Cambridge Companion to Theodore Dreiser (pp. 142159). Cambridge: Cambridge University Press.

Giles, P. (2004). Dreiser's style. In In L. Cassuto \& C. V. Eby (Eds.), The Cambridge Companion to Theodore Dreiser (pp. 47-62). Cambridge: Cambridge University Press.

Hakutani, Y. (1967). Sister Carrie and the Problem of Literary Naturalism. Twentieth Century Literature, 13 (1), 3-17.

Lukács, G. (1964). Studies in European Realism. New York: Grosset \& Dunlap.

Lukács, G. (1964). The Ideology of Modernism. In John \& Necke Mander (Trans.) Realism in Our Time, (pp. 17-46). New York: Harper and Row,

Lukács, G. (2007). Realism in the Balance. In Ronald Taylor (Ed.), Aesthetics and Politics (pp. 28-59). London: Verso.

Pizer, D. (1999). The Problem of American Literary Naturalism and Theodore Dreiser's "Sister Carrie". American Literary Realism, 32(1), 1-11.

Seltzer, L. F. (1976). Sister Carrie and the Hidden Longing for Love: Sublimation or Subterfuge? Twentieth Century Literature, 22(2), 192-209.

Wald, P. (2004). Dreiser's sociological vision. In L. Cassuto \& C. V. Eby (Eds.), The Cambridge Companion to Theodore Dreiser (pp. 177-195). Cambridge: Cambridge University Press.

Zola, E. (1963). The Experimental Novel. In George J. Becker (Ed.), Documents of Modern Literary Realism (pp.161-196). Princeton: Princeton Univ. Press.

Zola, E. (2014). Naturalism on the Stage. In Raman Selden (Ed.), The Theory of Criticism, From Plato to the Present: A Reader (pp. 5155). New York: Cambridge. 